\title{
ANALISIS KINERJA KEUANGAN PT WIJAYA KARYA BETON, Tbk SEBELUM DAN SESUDAH INITIAL PUBLIC OFFERING (IPO) TAHUN 2014
}

\author{
${ }^{1)}$ Zeze Zakaria Hamzah, ${ }^{2)}$ Suci Sumiati \\ ${ }^{1)}$ Dosen Program Studi Manajemen, STIE Dewantara \\ Jl. Raya Pemda Bojong Depok Baru III, Karadenan, Cibinong, Bogor, Jawa Barat 16913,Indonesia \\ Email: zeze.zakaria@dewantara.ac.id \\ ${ }^{2)}$ Alumni Program Studi Manajemen, STIE Dewantara \\ Jl. Raya Pemda Bojong Depok Baru III, Karadenan, Cibinong, Bogor, Jawa Barat 16913, Indonesia \\ Email: sucisumiati19@gmail.com
}

\begin{abstract}
The oretically the IPO decision gained a big influence in improving the company's condition and improving financial performance. The purpose of this study was to determine the level of financial health. PT Wijaya Karya Beton, Tbk before and after the IPO was measured using a financial ratio and assessed based on the Minister of BUMN Decree No. KEP-100 / MBU 12002. The results of this study are, measured by indicators of ROE ratio, ROI, collection periods and total asset turnover, it can be said that the IPO phenomenon does not have a sufficiently good impact on the financial performance of PT Wijaya Karya Beton, Tbk. While in the period after the IPO it can be said that the phenomenon of the IPO has a good impact on the financial performance of PT Wijaya Karya Beton, Tbk if measured by indicators of the ratio of cash ratios, current ratios, inventory turnover and TMS to TA. Based on BUMIN Ministerial Decree No. KEP-100 / MBU / 2002 on the financial aspects of PT Wijaya Karya Beton, Tbk, the soundness of financial performance in the period before and after the IPO can be said to be healthy with the same assessment of A. But when viewed from the total average weighted assessment, in the period before the IPO the value was better at 55.25 compared to the total average weighted valuation after the IPO period which was 51.16.
\end{abstract}

Keywords: Financial Performance, PT Wijaya Karya Beton, Tbk, Initial Public Offering (IPO), Financial Ratio.

\begin{abstract}
ABSTRAK
Secara teoritis keputusan IPO memperoleh pengaruh yang besar dalam memperbaiki kondisi perusaahaan dan peningkatan kinerja keuangan. Tujuan penelitian ini adalah untuk mengetahui tingkat kesehatan keuangan. PT Wijaya Karya Beton, Tbk sebelum dan sesudah IPO diukur menggunakan rasio keuangan dan dinilai berdasarkan SK Menteri BUMN No. KEP100/MBU/2002. Hasil dari penelitian ini adalah, diukur dengan indikator rasio ROE, ROI, collection periods dan perputaran total aset dapat dikatakan bahwa fenomena IPO tidak memberikan dampak yang cukup baik terhadap kinerja keuangan PT Wijaya Karya Beton, Tbk. Sedangkan pada periode setelah IPO dapat dikatakan bahwa fenomena IPO memberikan dampak baik terhadap kinerja keuangan PT Wijaya Karya Beton, Tbk jika diukur dengan indikator rasio rasio kas, rasio lancar, perputaran persediaan dan TMS terhadap TA. Berdasarkan SK Menteri BUMN No. KEP-100/MBU/2002 pada aspek keuangan PT Wijaya Karya Beton, Tbk, tingkat kesehatan kinerja keuangan pada periode sebelum dan sesudah IPO dapat dikatakan sehat dengan penilaian yang sama yaitu A. Namun jika dilihat dari total rata rata bobot penilaian, pada periode sebelum IPO nilainya lebih baik sebesar 55,25 dibandingkan total rata - rata bobot penilaian setelah periode IPO yakni sebesar 51,16.
\end{abstract}

Kata kunci: Kinerja Keuangan, PT Wijaya Karya Beton, Tbk, Initial Public Offering (IPO), Rasio Keuangan. 


\begin{tabular}{ll}
\hline \hline 1. PENDAHULUAN & efektifitas dan juga efesiensinya. \\
1.1 Latar Belakang & Penilaian kinerja keuangan perusahaan \\
Perusahaan memiliki beberapa pilihan & yang telah IPO ini menjadi fokus perhatian \\
dalam penambahan dana, antara lain & $\begin{array}{l}\text { semua kalangan. Oleh karena itu, peneliti } \\
\text { menggunakan keuntungan yang telah diraih }\end{array}$ \\
memiliki ide untuk melakukan penelitian \\
sebelumnya, meminjam dana dari bank, & mengenai kinerja keuangan PT Wijaya \\
serta menerbitkan saham atau obligasi. Jika & Karya Beton, Tbk sebelum dan sesudah \\
yang dpilih adalah menerbitkan saham atau & IPO ini sebagai topik penelitian, untuk \\
obligasi, maka perusahaan perlu melakukan & tujuan mendapatkan pemahaman apakah \\
penawaran umum atau Intial Public & terdapat perbedaan kinerja perusahaan \\
Offering (IPO) di pasar modal. Pada & dengan membandingkan kinerja keuangan \\
umumnya perusahaan yang telah IPO akan & sebelum dan sesudah menjadi perusahaan \\
memiliki dana lebih besar yang didapat dari & publik melalui analisis rasio keuangan.
\end{tabular}

penjualan sahamnya ke investor. Secara teoritis keputusan IPO memperoleh pengaruh yang besar dalam memperbaiki kondisi perusaahaan dan peningkatan kinerja keuangan (Inayah, 2011). Namun keputusan untuk melakukan IPO merupakan suatu keputusan yang kompleks, karena akan memunculkan adanya kerugian dan biaya baru (Gumanti, 2002; Midiastuti dan Ilyas, 2004; Wirajunayasa dan Putri, 2017), sehingga hal tersebut pastinya akan mempengaruhi kinerja keuangan perusahaan.

Dalam menilai kinerja keuangan perusahaan, dapat digunakan suatu indikator tertentu. Biasanya indikator yang digunakan adalah rasio atau indeks yang menghubungkan dua data keuangan. aktivitas. Selain menggunakan analisis keuangan, dalam mengukur tingkat kesehatan kinerja perusahaan BUMN dapat menggunakan indikator berdasarkan SK Menteri BUMN No. KEP-100/MBU/2002 yang diterbitkan oleh pemerintah pada tahun 2002 guna mendorong perusahaan perusahaan yang merupakan bagian dari BUMN agar menjalankan usahanya lebih efektif dan efisien.

Hasil dari analisis terhadap rasio-rasio keuangan dan penilaian tingkat kesehatan berdasarkan SK Menteri BUMN No. KEP100/MBU/2002 tersebut dapat memberikian penjelasan mengenai pencapaian kinerja perusahaan perusahaan termasuk menilai

\subsection{Ruang Lingkup Permasalahan}

Penelitian ini difokuskan dengan membandingkan kondisi keuangan PT Wijaya Karya Beton, Tbk sebelum dengan sesudah IPO periode 2011-2017. Kondisi kinerja keuangan dianalisis dengan rasio keuangan dan dibandingkan dengan analisis deskriptif.

\subsection{Perumusan Masalah}

Penelitian ini merumuskan masalah dalam penelitian ini sebagai berikut:

1. Bagaimana kinerja keuangan perusahaan PT Wijaya Karya Beton, Tbk sebelum dan sesudah IPO diukur dengan menggunakan rasio keuangan?

2. Bagaimana tingkat kesehatan keuangan PT Wijaya Karya Beton, Tbk sebelum dan sesudah IPO dinilai berdasarkan SK Menteri BUMN No. KEP-100/MBU/2002?

\subsection{Tujuan Penelitian}

Tujuan dibuatnya penelitian ini adalah sebagai berikut:

1. Untuk mengetahui bagaimana kinerja keuangan perusahaan PT. Wijaya Karya Beton, Tbk sebelum dan sesudah IPO diukur dengan menggunakan rasio keuangan.

2. Untuk mengetahui tingkat kesehatan keuangan PT Wijaya Karya Beton, 
Tbk sebelum dan sesudah IPO dinilai berdasarkan SK Menteri BUMN No. KEP-100/MBU/2002.

\section{TINJAUAN PUSTAKA}

\subsection{Landasan Teori}

\subsubsection{Kinerja Keuangan Perusahaan}

Kinerja keuangan adalah gambaran pencapaian kinerja keauangan suatu perusahaan. Jumingan (2011:293) mendefinisikan bahwa kinerja keuangan adalah gambaran kondisi keuangan perusahaan pada suatu periode tertentu baik menyangkut aspek penghimpunan dana maupun penyaluran dana, yang biasanya diukur dengan indikator kecukupan modal, likuiditas, dan profitabilitas.

Hasil penilaian kinerja juga dapat dijadikan sebagai alat evaluasi kinerja manajemen apakah perusahaan telah bekerja secara efektif atau tidak. Jika berhasil mencapai target yang ditentukan bisa dikatakan bahwa perusahaan berhasil bekerja secara efektif. Namun, sebaliknya jika tidak berhasil mencapai target yang telah ditentukan, ini akan menjadi pelajaran bagi manajemen untuk periode kedepan.

\subsubsection{Laporan Keuangan}

Ikatan Akuntan Indonesia dalam Standar Akuntansi Keuangan PSAK No. 1 (2017: 09) mengemukakan bahwa: "Laporan keuangan adalah suatu penyajian terstruktur dari posisi keuangan dan kinerja keuangan suatu entitas. Tujuan laporan keuangan adalah untuk memberikan informasi mengenai posisi keuangan, kinerja keuangan, dan arus kas entitas yang bermanfaat bagi sebagian besar pengguna laporan keuangan dalam pembuatan keputusan ekonomik. Laporan keuangan juga menunjukan hasil pertanggungjawaban manajemen atas penggunaan sumber daya yang dipercayakan kepada mereka. Dalam rangka mencapai tujuan tersebut laporan keuangan menyajikan informasi mengenai entitas yang meliputi: aset, liabilitas, ekuitas, penghasilan dan beban, kontribusi, arus kas".

\subsubsection{Analisis Laporan Keuangan}

Analisis laporan keuangan (financial statement analysis) pada dasarnya merupakan perhitungan rasio-rasio untuk menilai keadaan keuangan perusahaan di masa lalu, saat ini dan kemungkinannya di masa depan. Analisis laporan keuangan yang dilakukan dimaksudkan untuk menambah informasi yang ada dalam suatu laporan keuangan

Menurut Munawir (2010:31), menyebtukan bahwa analisa laporan keuangan terdiri dari penelahaan atau mempelajari dari pada hubungan-hubungan atau kecenderungan untuk menentukan posisi keuangan dan operasi serta perkembangan usaha yang bersangkutan. Dengan diadakannya analisa laporan keuangan ini diharapkan dapat dihasilkan informasi yang berguna bagi pihak yang berpentingan.

\subsubsection{Analisis Rasio Keuangan}

Dalam rangka untuk mengevaluasi kinerja dan kondisi keuangan perfusahaan, analisis keuangan maupun pemakai laporan keuangan harus melakukan analisis terhadap tingkat kesehatan perusahaan. Alat yang biasa digunakan untuk mengukur dan dan mengevaluasi kinerja dan kondis keuangan perusahaan tersebut adalah analisis rasio keuangan (financial ratio analysis).

Untuk mengukur tingkat kesehatan BUMN dapat diukur dengan membandingkan realisasi hasil perhitungan rasio keuangan dengan pedoman penilaian kesehatan BUMN yang tertuang dalam Surat Keputusan Menteri BUMN No. KEP-100/MBU/2002 tanggal 4 Juni 2002.

Berdasakan Surat Keputusan Menteri BUMN No. KEP-100/MBU/2002, penilaian kinerja berpedoman pada besarnya bobot yang diperoleh perusahaan. Untuk 
menentukan tingkat kesehatan tersebut ditetapkan berdasarkan penilaian terhadap kinerja perusahaan untuk tahun buku yang bersangkutan, yang meliputi tiga aspek penilaian yaitu aspek keuangan, aspek operasional dan aspek administrasi.

Penilaian tingkat kesehatan BUMN berlaku bagi seluruh BUMN non jasa keuangan yang diatur dalam Surat Keputusan Menteri Badan Usaha Milik Negara No: KEP-100/MBU/2002. Penilaian tingkat kesehatan BUMN yang bergerak dibidang non jasa keuangan dibedakan antara BUMN yang bergerak dalam bidang infrastruktur dan BUMN yang bergerak dalam bidang non infrastruktur.

Berdasarkan Surat Keputusan Menteri BUMN No. KEP-100/MBU/2002 dalam penilaian aspek keuangan, indikator yang dinilai serta bobot - bobotnya adalah sebagai berikut:

Tabel 1. Daftar Tabel Indikator dan Bobot Aspek Keuangan

\begin{tabular}{|l|c|c|}
\hline \multirow{2}{*}{\multicolumn{1}{|c|}{ Indikator }} & \multicolumn{2}{|c|}{ Bobot } \\
\cline { 2 - 3 } & Infrastruktur & $\begin{array}{c}\text { Non } \\
\text { Infrastruktur }\end{array}$ \\
\hline $\begin{array}{l}\text { 1. Imbalan kepada pemegang } \\
\text { saham (ROE) }\end{array}$ & 15 & 20 \\
\hline 2. Imbalan Investasi (ROI) & 10 & 15 \\
\hline 3. Rasio Kas & 3 & 5 \\
\hline 4. Rasio Lancar & 4 & 5 \\
\hline 5. Collection Periods & 4 & 5 \\
\hline 6. Perputaran Persediaan & 4 & 5 \\
\hline 7. Perputaran Total Asset & 4 & 5 \\
\hline $\begin{array}{l}\text { 8. Rasio modal sendiri } \\
\text { terhadap total Aktiva }\end{array}$ & 6 & 10 \\
\hline \multicolumn{1}{|c|}{ Total Bobot } & 50 & 70 \\
\hline
\end{tabular}

Sumber : Surat Keputusan Menteri BUMN No. KEP-100/MBU/2002

\subsubsection{Pasar Modal dan Initial Public Offering (IPO)}

Definisi Pasar Modal berdasar informasi di Bursa Efek Indonesia adalah pasar modal (capital market) merupakan pasar untuk berbagai instrumen keuangan jangka panjang yang bisa diperjualbelikan, baik surat utang (obligasi), ekuiti (saham), reksa dana, instrumen derivatif maupun instrumen lainnya. Pasar modal merupakan sarana pendanaan bagi perusahaan maupun institusi lain (misalnya pemerintah), dan sebagai sarana bagi kegiatan berinvestasi.

IPO adalah merupakan sebuah singkatan dari Initial Public Offering atau apabila diartikan dalam Bahasa Indonesia yaitu Penawaran Umum Perdana, yang artinya inilah waktu ketika sebuah perusahaan melaksanakan penjualan saham untuk yang pertama kali kepada masyarakat yang sering kita sebut sebagai investor. Aktifitas IPO ini akan secara otomatis diikuti dengan pendaftaran saham perusahaan di Bursa Efek, maka kemudian saham-saham yang telah melakukan IPO tersebut akan dapat diperjualbelikan melalui Bursa (Payamta dan Machfoedz, 1999; Indrianto Setiawan, 2007).

\subsection{Kerangka Penelitian}

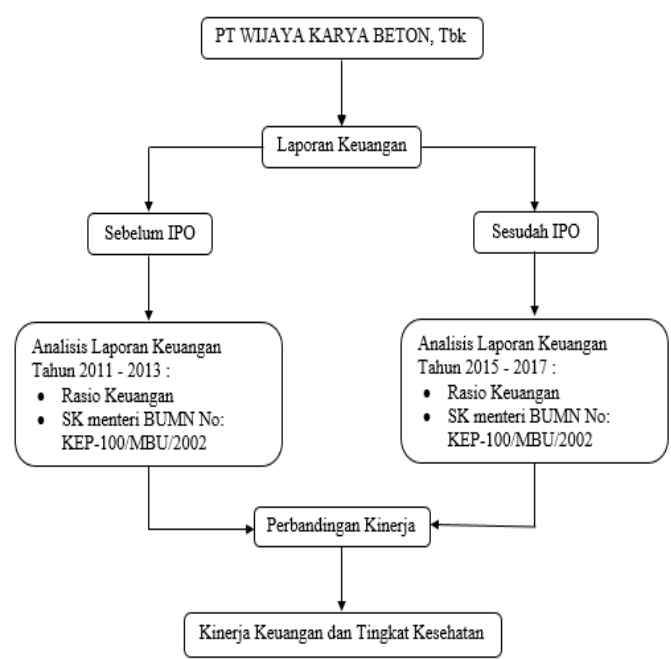

Gambar 1. Kerangka Penelitian

3. METODE PENELITIAN

\subsection{Jenis Penelitian}

Penelitian ini menggunakan pendekatan kuantitatif yaitu mngklasifikasikan, menghitung, membandingkan dan menganalisis data (Inayah, 2011). Dalam penelitian ini data yang dimaksud adalah laporan keuangan PT 
Wijaya Karya Beton, Tbk periode 2011 2017.

Selain itu penelitian ini termasuk ke dalam jenis penelitian deskriptif komparatif yaitu penelitian yang bertujuan untuk mendeskripasikan secara sistematis, faktual dan akurat yang kemudian data - data tersebut diperbandingkan antar periode sebelum dan sesudah terjadinya suatu fenomena, yang dalam hal ini fenomena go public (Purnomoratih, 2008).

\subsection{Variabel Penelitian}

Variabel penelitian dalam penelitian ini adalah rasio keuangan yang terdapat pada SK Menteri BUMN No. KEP100/MBU/2002 dihitung berdasarkan laporan keuangan pada PT Wijaya Karya Beton, Tbk 3 (tiga) tahun sebelum IPO yaitu tahun 2011-2013 dan 3 (tiga) tahun sesudah IPO yaitu tahun 2015-2017.

\subsection{Lokasi dan Waktu Penelitian}

Lokasi yang digunakan dalam penelitian ini adalah situs Bursa Efek Indonesia (BEI) yaitu www.idx.com dan situs resmi PT Wijaya Karya Beton, Tbk yaitu www.wika-beton.co.id . Sedangkan untuk waktu penelitian dimulai dari bulan November 2018 - Mei 2019.

\subsection{Objek Penelitian}

Objek dalam penelitian ini adalah PT Wijaya Karya Beton Tbk (WIKA Beton), yang merupakan salah satu anak perusahaan dari PT Wijaya Karya (Persero), Tbk (WIKA), merupakan bagian dari ekspansi perusahaan yang mengkhususkan diri dalam industri beton pracetak yang telah melakukan IPO pada tahun 2014 sedangkan objek penelitian adalah laporan keuangan PT Wijaya Karya beton, Tbk periode 20112017.

\subsection{Populasi dan Sampel}

Dalam penelitian ini yang dijadikan populasi adalah laporan keuangan tahunan
PT Wijaya Karya Beton, Tbk yang diterbitkan pada situs resmi perusahaan dan juga Bursa Efek Indonesia yakni laporan keuangan.

Sehingga sample yang digunakan pada penelitian ini meliputi semua populasi yang ada yakni laporan keuangan PT Wijaya Karya Beton, Tbk periode tahun 2011 2017.

\subsection{Teknik Pengumpulan Data}

Pada penelitian ini data yang dikumpulkan melalui metode observasi non partisipasi, yaitu metode mengamati dan menelaah dokumentasi. Teknik pengumpulan data dilakukan dengan metode dokumentasi terhadap data sekunder. Dalam penelitian ini yang merupakan sumber data utama adalah laporan keuangan PT Wijaya Karya Beton, Tbk periode $2011-2017$.

\subsection{Teknik Analisis Data}

Penelitian ini menggunakan metode analisis data yang digunakan dalam penelitian ini adalah rasio keuangan dan penilaian tingkat kesehatan BUMN pada aspek keuangan sesuai SK Menteri BUMN No. KEP-100/MBU/2002 untuk perusahaan non infrastruktur. Analisis ini menggunakan pendekatan kuantitatif dengan jenis deskriptif komparatif.

Adapaun langkah-langkahnya sebagai berikut:

a. Melakukan perhitungan terhadap object penelitian dengan rumus-rumus rasio keuangan dan memberikan skor pada tiap - tiap rasio keuangan sesuai indikator penilaian tingkat kesehatan BUMN pada aspek keuangan sesuai SK Menteri BUMN No.KEP100/MBU/2002 .

b. Mendeskripsikan hasil perhitungan terhadap object penelitian dengan rumus - rumus rasio keuangan dan nilai skor yang di dapatkan tiap - tiap rasio berdasarkan penilaian tingkat 
kesehatan BUMN pada aspek keuangan sesuai SK Menteri BUMN No. KEP-100/MBU/2002, kemudian melakukan perbandingan nilai sebelum dan sesudah IPO.

c. Melakukan perhitungan nilai bobot dan menentukan kondisi kesehatan perusahaan berdasarkan penilaian tingkat kesehatan BUMN pada aspek keuangan sesuai SK Menteri BUMN No. KEP-100/MBU/2002, kemudian dicari nilai rata - rata bobot masing periode yaitu periode sebelum dan sesudah IPO.

Adapun penilaian bobot masingmasing indikator sebagai berikut:

Tabel 2. Daftar Indikator dan Bobot Aspek Keuangan BUMN Non Infrastruktur

\begin{tabular}{|c|l|c|}
\hline No. & \multicolumn{1}{|c|}{ Indikator } & $\begin{array}{c}\text { Bobot BUMN } \\
\text { Non } \\
\text { Infrastruktur }\end{array}$ \\
\hline 1 & ROE & 20 \\
\hline 2 & ROI & 15 \\
\hline 3 & Cash Ratio & 5 \\
\hline 4 & Current Ratio & 5 \\
\hline 5 & Collection Periode & 5 \\
\hline 6 & Perputaran Persediaan & 5 \\
\hline 7 & Total Asset Turnover & 5 \\
\hline 8 & TMS terhadap TA & 10 \\
\hline \multicolumn{2}{|c|}{ Total } & 70 \\
\hline
\end{tabular}

Sumber: SK Menteri BUMN No. KEP100/MBU/2002

Hasil perhitungan dari total skor keuangan (TSK) dikalikan dengan total nilai keseluruhan (TS) menjadi:

AAA apabila total skor keuangan (TSK) $>66,5$
AA apabila $56<$ TSK $<=66,5$
A apabila $45,5<$ TSK $<=56$

KURANG SEHAT, yang terdiri dari:

BBB apabila $35<$ TSK $<=45,5$

BB apabila $28<$ TSK $<=35$
B

apabila $21<$ TSK $<=28$

TIDAK SEHAT, yang terdiri dari:

CCC apabila $14<$ TSK $<=21$

$\mathrm{CC}$ apabila $7<\mathrm{TSK}<=14$

C apabila TSK $<=7$

d. Melakukan perbandingan dan mendeskripsikan nilai bobot dan tingkat kesehatan perusahaan berdasarkan penilaian tingkat kesehatan BUMN pada aspek keuangan sesuai SK Menteri BUMN No. KEP-100/MBU/2002 antar periode sebelum dan sesudah IPO dengan menggunakan analisis trend.

\section{HASIL DAN PEMBAHASAN}

4.1 Analisis Data Dengan Rasio Keuangan dan Skor SK Menteri BUMN No. KEP-100MBU/2002.

\subsubsection{Imbalan Kepada Pemegang Saham / Return On Equity ( ROE )}

$$
\text { ROE }=\frac{\text { Laba Setelah Pajak }}{-} \frac{\text { Modal Sendiri }}{\text { x 100\% }}
$$

Artinya setiap Rp1,00 total modal sendiri mampu menghasilkan laba setelah pajak sebesar $(\mathrm{x})$ rupiah

Tabel 3. Penilaian ROE (Dinyatakan dalam Rupiah)

\begin{tabular}{|c|c|c|c|c|}
\hline Tahun & $\begin{array}{c}\text { Laba Setelah } \\
\text { Pajak }\end{array}$ & $\begin{array}{c}\text { Modal } \\
\text { Sendiri }\end{array}$ & Rasio \% & Skor \\
\hline 2011 & 144.422 .907 & 429.694 .686 & 33,61 & 20 \\
\hline 2012 & 179.368 .111 & 604.329 .779 & 29,68 & 20 \\
\hline 2013 & 241.206 .242 & 730.017 .770 & 33,04 & 20 \\
\hline $\mathbf{2 0 1 4}$ & $\mathbf{3 2 2 . 4 0 3 . 8 5 1}$ & 2.225 .777 .452 & 14,48 & $\mathbf{1 8}$ \\
\hline 2015 & 158.567 .977 & 2.263 .425 .161 & 7,01 & 10 \\
\hline 2016 & 278.628 .016 & 2.491 .233 .447 & 11,18 & 16 \\
\hline 2017 & 338.417 .312 & 2.747 .935 .334 & 12,32 & 16 \\
\hline
\end{tabular}

Sumber: Data yang telah diolah

Jika dilakukan perbandingan indikator rasio return on equity antar periode sebelum 
dan sesudah IPO, dapat dikatakan nilai return on equity sebelum IPO lebih baik dibandingkan nilai return on equity sesudah IPO.

\subsubsection{Imbalan Investasi / Return On Investment ( ROI )}

$$
\mathrm{ROI}=\frac{\text { EBIT }+ \text { Penyusutan }}{\text { Capital Employed }}
$$

Artinya setiap Rp1,00 capital employed yang digunakan mampu menghasilkam EBIT + penyusutan sebesar (x) rupiah.

\section{Tabel 4. Penilaian ROI (Dinyatakan dalam Rupiah)}

\begin{tabular}{|c|c|c|c|c|}
\hline Tahun & $\begin{array}{c}\text { EBIT + } \\
\text { Penyusutan }\end{array}$ & $\begin{array}{c}\text { Capital } \\
\text { Employed }\end{array}$ & Rasio \% & Skor \\
\hline 2011 & 214.137 .029 & 1.792 .729 .735 & 11,94 & 9 \\
\hline 2012 & 276.235 .370 & 2.313 .918 .394 & 11.94 & 9 \\
\hline 2013 & 392.982 .851 & 2.795 .386 .632 & 14,06 & 12 \\
\hline $\mathbf{2 0 1 4}$ & $\mathbf{4 9 0 . 2 8 3 . 6 3 4}$ & 3.501 .007 .865 & 14 & 12 \\
\hline 2015 & 315.382 .856 & 4.252 .075 .104 & 7,42 & 6 \\
\hline 2016 & 516.434 .809 & 4.376 .324 .668 & 11,8 & 9 \\
\hline 2017 & 681.305 .522 & 6.620 .648 .060 & 10,29 & 7,5 \\
\hline
\end{tabular}

Sumber: Data sekunder yang diolah

Jika dilakukan perbandingan indikator rasio return on invesment antar periode sebelum dan sesudah IPO, dapat dikatakan nilai return on invesment sebelum IPO lebih baik dibandingkan nilai return on invesment sesudah IPO.

\subsubsection{Rasio Kas / Cash Ratio}

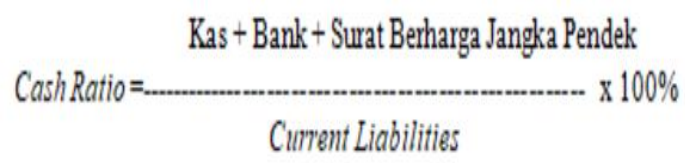

Artinya setiap Rp1,00 current liabilities dijamin oleh kas sekian ( $\mathrm{x}$ ) rupiah.
Tabel 5. Penilaian Rasio (Dinyatakan dalam Rupiah)

\begin{tabular}{|c|c|c|c|c|}
\hline Tahun & $\begin{array}{c}\text { Kas } \\
\text { \& } \\
\text { Setara Kas }\end{array}$ & $\begin{array}{c}\text { Current } \\
\text { Liabilities }\end{array}$ & $\begin{array}{c}\text { Rasio } \\
\%\end{array}$ & Skor \\
\hline 2011 & 225.719 .987 & 1.402 .903 .914 & 16,09 & 3 \\
2012 & 340.319 .362 & 1.778 .015 .476 & 19,14 & 3 \\
2013 & 413.026 .822 & 1.794 .348 .077 & 23,02 & 3 \\
\hline $\mathbf{2 0 1 4}$ & $\mathbf{1 . 0 3 8 . 4 7 4 . 6 9 9}$ & $\mathbf{1 . 5 0 9 . 5 3 1 . 4 7 6}$ & $\mathbf{6 8 , 7 9}$ & 5 \\
\hline 2015 & 823.630 .867 & 1.793 .464 .704 & 45,92 & 5 \\
2016 & 342.211 .215 & 1.863 .793 .637 & 18,36 & 3 \\
2017 & 637.755 .397 & 4.216 .314 .369 & 15,13 & 3 \\
\hline
\end{tabular}

Sumber: Data yang telah diolah

Jika dilakukan perbandingan indikator rasio kas antar periode sebelum dan sesudah IPO, dapat dikatakan nilai rasio kas sebelum IPO tidak lebih baik dibandingkan nilai rasio kas sesudah IPO.

\subsubsection{Rasio Lancar / Current Ratio Current Asset}

Current Ratio $=$

\section{Current Liabilities}

Artinya setiap Rp1,00 current liabilities dijamin sekian (x) rupiah current asset.

Tabel 6. Penilaian Rasio Lancar (Dinyatakan dalam Rupiah)

\begin{tabular}{|c|c|c|c|c|}
\hline Tahun & $\begin{array}{c}\text { Current } \\
\text { Asset }\end{array}$ & $\begin{array}{c}\text { Current } \\
\text { Liabilities }\end{array}$ & $\begin{array}{c}\text { Rasio } \\
\%\end{array}$ & Skor \\
\hline 2011 & 1.391 .940 .834 & 1.402 .903 .914 & 99,22 & 2 \\
2012 & 1.793 .979 .565 & 1.778 .015 .476 & 100,90 & 3 \\
2013 & 1.896 .017 .938 & 1.794 .348 .077 & 105,67 & 3 \\
\hline 2014 & 2.127 .039 .037 & 1.509 .531 .476 & 140,91 & $\mathbf{5}$ \\
\hline 2015 & 2.454 .908 .918 & 1.793 .464 .704 & 136,88 & 5 \\
2016 & 2.439 .936 .920 & 1.863 .793 .637 & 130,91 & 5 \\
2017 & 4.351 .377 .174 & 4.216 .314 .369 & 103,20 & 3 \\
\hline
\end{tabular}

Sumber: Data sekunder yang diolah

Jika dilakukan perbandingan indikator rasio lancar antar periode sebelum dan sesudah IPO, dapat dikatakan nilai rasio lancar sebelum IPO tidak lebih baik dibandingkan nilai rasio lancar sesudah IPO. 


\begin{tabular}{|c|c|c|c|c|c|}
\hline \multirow{2}{*}{\multicolumn{6}{|c|}{1.5}} \\
\hline & & & & & \\
\hline \multirow{3}{*}{$\mathrm{CP}=$} & \multicolumn{5}{|c|}{ Total Piutang usaha } \\
\hline & 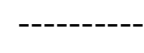 & 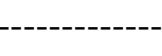 & 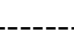 & $365 \mathrm{~h}$ & \\
\hline & \multicolumn{5}{|c|}{ Total Pendapatan Usaha } \\
\hline \multicolumn{6}{|c|}{$\begin{array}{l}\text { Artinya dalam setahun piutang dapat } \\
\text { dikumpulkan setiap (x) hari sekali dalam } \\
\text { setahun. }\end{array}$} \\
\hline \multicolumn{6}{|c|}{$\begin{array}{l}\text { Tabel 7. Penilaian Collection Periods } \\
\text { (Dinyatakan dalam Rupiah) }\end{array}$} \\
\hline Tahum & $\begin{array}{l}\text { Total } \\
\text { Piutang } \\
\text { Usaha }\end{array}$ & \begin{tabular}{|c|} 
Total \\
Pendapatan \\
Usaha
\end{tabular} & $\begin{array}{c}\text { Rasio } \\
\text { /hari }\end{array}$ & Perbaikan & Skor \\
\hline 2011 & 306.955 .286 & 1.635 .086 .530 & 69 & . & 4,5 \\
\hline 2012 & 309.418 .630 & 2.030 .596 .831 & 56 & 13 & 5 \\
\hline 2013 & 421.906 .489 & 2.643 .724 .434 & 58 & - & 5 \\
\hline 2014 & 475.688 .831 & 3.277 .195 .052 & 53 & 5 & 5 \\
\hline 2015 & 570.108 .563 & 2.652 .622 .140 & 78 & - & 4,5 \\
\hline 2016 & 653.482 .031 & 3.481 .731 .506 & 69 & 9 & 4,5 \\
\hline 2017 & 1.219 .478 .280 & 5.362 .263 .238 & 83 & - & 4,5 \\
\hline
\end{tabular}

Sumber: Data sekunder yang diolah

Jika dilakukan perbandingan indikator collection periods antar periode sebelum dan sesudah IPO, dapat dikatakan nilai collection periods sebelum IPO lebih baik sebesar 5 dibandingkan nilai collection periods sesudah IPO sebesar 4,5.

\subsubsection{Perputaran Persediaan / Inventory Turnover}

$$
\mathrm{PP}=\frac{\text { Total Persediaan }}{\text { Total Pendapatan Usaha }}
$$

Artinya perputaran persediaan terjadi dalam (x) hari sekali dalam setahun.

Tabel 8. Perputaran
(Dinyatakan dalam Rupiah)

\begin{tabular}{|c|c|c|c|c|c|}
\hline Tahun & $\begin{array}{c}\text { Total } \\
\text { Persediaan }\end{array}$ & $\begin{array}{c}\text { Total } \\
\text { Pendapatan } \\
\text { Usaha }\end{array}$ & $\begin{array}{c}\text { Rasio } \\
\text { hari }\end{array}$ & Perbaikan & Skor \\
\hline 2011 & 704.070 .171 & 1.635 .086 .530 & 157 & - & 3 \\
2012 & 881.216 .572 & 2.030 .596 .831 & 158 & - & 3 \\
2013 & 846.026 .589 & 2.643 .724 .434 & 117 & 41 & 5 \\
\hline 2014 & 457.603 .143 & 3.277 .195 .052 & 51 & 66 & 5 \\
\hline 2015 & 622.479 .998 & 2.652 .622 .140 & 86 & - & 4,5 \\
2016 & 694.463 .252 & 3.481 .731 .506 & 73 & 13 & 4,5 \\
2017 & 1.034 .176 .711 & 5.362 .263 .238 & 70 & 3 & 4,5 \\
\hline
\end{tabular}

Sumber: Data sekunder yang diolah

Jika dilakukan perbandingan indikator rasio perputaran persediaan antar periode sebelum dan sesudah IPO, dapat dikatakan nilai perputaran persediaan sebelum IPO tidak lebih baik dibandingkan nilai perputaran persediaan sesudah IPO.

\subsubsection{Perputaran Aset / Total Asset} Turnover

Total Pendapatan

$$
\text { TATO }=\text { Capital Employed }
$$

Artinya setiap Rp 1,00 capital employed mampu menghasilkan total pendapatan sekian $(\mathrm{x})$ rupiah.

Tabel 9. Penilaian Perputaran Total Aset (Dinyatakan dalam Rupiah)

\begin{tabular}{|c|c|c|c|c|c|}
\hline Tahun & $\begin{array}{c}\text { Total } \\
\text { Pendapatan }\end{array}$ & $\begin{array}{c}\text { Capital } \\
\text { Employed }\end{array}$ & $\begin{array}{c}\text { Rasio } \\
\%\end{array}$ & Perbaikan & Skor \\
\hline 2011 & 1.635 .086 .530 & 1.792 .729 .735 & 91,21 & - & 4 \\
2012 & 2.030 .596 .831 & 2.313 .918 .394 & 87,76 & - & 3,5 \\
2013 & 2.643 .724 .434 & 2.795 .386 .632 & 94,57 & 6,81 & 4 \\
\hline 2014 & 3.277 .195 .052 & 3.501 .007 .865 & 93,61 & - & 4 \\
\hline 2015 & 2.652 .622 .140 & 4.252 .075 .104 & 62,38 & - & 3 \\
2016 & 3.481 .731 .506 & 4.376 .324 .668 & 79,56 & 17.18 & 4,5 \\
2017 & 5.362 .263 .238 & 6.620 .648 .060 & 80,99 & 1,43 & 3,5 \\
\hline
\end{tabular}

Sumber: Data sekunder yang diolah

Jika dilakukan perbandingan indikator rasio perputaran total aset antar periode sebelum dan sesudah IPO, dapat dikatakan nilai perputaran total aset sebelum IPO 
lebih baik yakni sebesar 4 kali dibandingkan nilai perputaran total aset sesudah IPO sebesar 3 kali.

\subsubsection{Rasio Total Modal Sendiri} Terhadap Total Aktiva / TMS Terhadap TA

TMS Terhadap TA $=\frac{\text { Total Modal Sendiri }}{- \text { Total Asset }}$

Artinya setiap $\mathrm{Rp} 1,00$ total modal sendiri dapat digunakan untuk membiayai aktiva perusahaan $(\mathrm{x})$ rupiah.

Tabel 10. Penilaian TMS Terhadap TA (Dinyatakan dalam Rupiah)

\begin{tabular}{|c|c|c|c|c|}
\hline Tahum & $\begin{array}{c}\text { Total } \\
\text { Modal } \\
\text { Sendiri }\end{array}$ & $\begin{array}{c}\text { Total } \\
\text { Asset }\end{array}$ & $\begin{array}{c}\text { Rasio } \\
\%\end{array}$ & Skor \\
\hline 2011 & 429.694 .686 & 1.838 .842 .712 & 23,37 & 7,25 \\
2012 & 604.329 .779 & 2.401 .099 .745 & 25,17 & 7,25 \\
2013 & 730.017 .770 & 2.917 .400 .751 & 25,02 & 7,25 \\
\hline $\mathbf{2 0 1 4}$ & 2.225 .777 .452 & 3.802 .332 .940 & 58,54 & 8,5 \\
\hline 2015 & 2.263 .425 .161 & 4.456 .097 .503 & 50,79 & 8,5 \\
2016 & 2.491 .233 .447 & 4.663 .078 .319 & 53,42 & 8,5 \\
2017 & 2.747 .935 .334 & 7.067 .976 .095 & 38,88 & 10 \\
\hline
\end{tabular}

Sumber: Data sekunder yang diolah

Jika dilakukan perbandingan indikator rasio TMS terhadap TA antar periode sebelum dan sesudah IPO, dapat dikatakan nilai TMS terhadap TA sebelum IPO tidak lebih baik yakni sebesar 7,25 dibandingkan nilai TMS terhadap TA sesudah IPO sebesar 10.

\subsection{Total Bobot Kinerja Keuangan Berdasar dengan SK Menteri BUMN No. KEP-100MBU/2002.}

Di bawah ini adalah hasil penilaian skor terhadap delapan indikator rasio keuangan yang diteliti dan dinilai bobotnya sesuai SK Menteri BUMN No. KEP100/MBU/2002:
Tabel 11. Kriteria Penilaian Tingkat kesehatn BUMN pada Aspek Keuangan sesuai SK Menteri BUMN No. KEP100/MU/2002

\begin{tabular}{|c|c|c|c|c|c|c|c|c|}
\hline & & \multicolumn{3}{|c|}{ Sebelum } & \begin{tabular}{|l|} 
IPO \\
\end{tabular} & \multicolumn{3}{|c|}{ Sesudah } \\
\hline No. & Indikater & 2011 & 2012 & 2013 & 2014 & 2015 & 2016 & 2017 \\
\hline 1 & ROE & 20 & 20 & 20 & 18 & 10 & 16 & 16 \\
\hline 2 & & & & 12 & 12 & & 9 & 7,5 \\
\hline 3 & Rasio Kas & 3 & & & 6 & 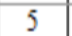 & 3 & 3 \\
\hline 4 & Rasio Lancar & 2 & & & & 5 & 5 & 3 \\
\hline 5 & $\begin{array}{c}\text { Collection } \\
\text { Periode }\end{array}$ & 4,5 & 5 & 5 & 5 & 4,5 & 4,5 & 4,5 \\
\hline 6 & & 3 & 3 & 5 & 5 & 4,5 & 4,5 & 4,5 \\
\hline 7 & & 4 & 3,5 & 4 & 4 & 3 & 4,5 & 3,5 \\
\hline 8 & $\begin{array}{c}\text { TMS } \\
\text { terhadap TA }\end{array}$ & 7,25 & 7,25 & 7,25 & 8,5 & 8,5 & 8,5 & 10 \\
\hline & Total Bobet & 52,75 & 53,75 & 59,25 & 62,5 & 46,5 & 55 & 52 \\
\hline & Rata - Rata & & 55,25 & & & & 51,16 & \\
\hline & Penilai & & A & & & & A & \\
\hline & $\mathrm{K}$ & & SEHAI & & & & SEHA & \\
\hline
\end{tabular}

Sumber: Data skunder yang diolah

Berikut gambar trand dari total bobot tingkat kesehatan kinerja keuangan PT WIjaya Karya Beton, Tbk sebelum dan sesudah IPO tahun 2011 - 2017:

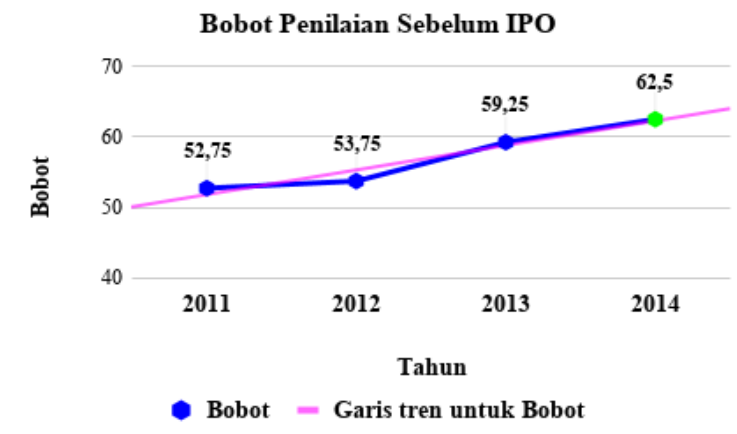

Gambar 2. Trend Bobot Penilaian Sebelum IPO

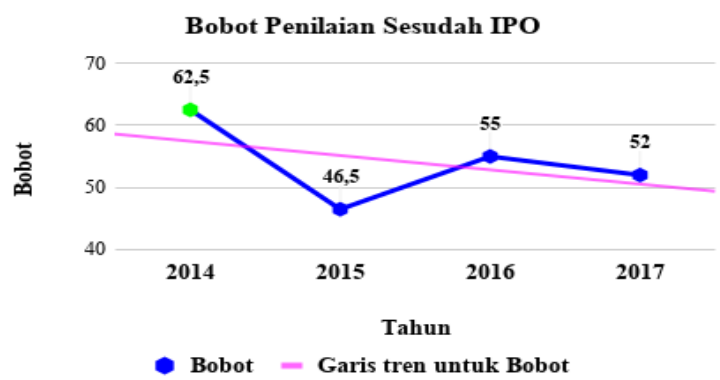

Gambar 3. Trend Bobot Penilaian 
Berdasarkan tabel dan trand di atas, setelah dilakukan perhitungan nilai rata rata bobot kriteria penilaian tingkat kesehatan BUMN berdasarkan SK Menteri BUMN No. KEP-100/MBU/2002 pada aspek keuangan PT Wijaya Karya Beton, Tbk sebesar 55,25 dapat dikatakan sehat dengan penilaian A. Begitupula pada tahun 2015 - 2017 sebesar 51,16 dapat dikatakan sehat dengan penilaian A.

Sesuai data dan keterangan di atas dapat disimpulkan bahwa Berdasarkan SK Menteri BUMN No. KEP-100/MBU/2002 pada aspek keuangan PT Wijaya Karya Beton, Tbk, tingkat kesehatan kinerja keuangan pada periode sebelum dan sesudah IPO dapat dikatakan sehat dengan penilaian yang sama yaitu A. Namun jika dilihat dari total rata - rata bobot penilaian, pada periode sebelum IPO nilainya lebih baik dibandingkan total rata - rata bobot penilaian setelah periode IPO.

\section{KESIMPULAN DAN SARAN}

\subsection{Kesimpulan}

Berdasarkan penelitian analisis kinerja keuangan PT Wijaya Karya Beton Tbk sebelum dan sesudah IPO dengan menggunakan indikator rasio keuangan dan penilaian tingkat kesehatan BUMN berdasarkan SK Menteri BUMN No. KEP100/MBU/2002 pada aspek keuangan, maka dapat di ambil kesimpulan sebagai berikut:

1. Pada periode sebelum IPO, empat dari delapan indikator rasio yang digunakan yaitu ROE, ROI, collection periods dan perputaran total asset menunjukan kinerja yang lebih baik dibandingkan periode setelah IPO. Dapat dikatakan bahwa fenomena IPO tidak memberikan dampak yang cukup baik terhadap kinerja keuangan PT Wijaya Karya Beton, Tbk jika diukur dengan indikator rasio ROE, ROI, collection periods dan perputaran total aset. Sedangkan pada empat indikator rasio lainnya yaitu rasio kas, rasio lancar, perputaran persediaan dan TMS terhadap TA menunjukan hasil yang sebaliknya, dimana pada periode setelah IPO empat indikator rasio tersebut menunjukan hasil yang lebih baik dari pada periode sebelum IPO. Dapat dikatakan bahwa fenomena IPO memberikan dampak baik terhadap kinerja keuangan PT Wijaya Karya Beton, Tbk jika diukur dengan indikator rasio kas, rasio lancar, perputaran persediaan dan TMS terhadap TA

2. Berdasarkan Surat Keputusan Menteri BUMN No. KEP-100/MBU/2002 pada aspek keuangan PT Wijaya Karya Beton, Tbk, tingkat kesehatan kinerja keuangan pada periode sebelum dan sesudah IPO dapat dikatakan sehat dengan penilaian yang sama yaitu A. Namun jika dilihat dari total rata - rata bobot penilaian, pada periode sebelum IPO nilainya lebih baik yakni sebesar 55,25 dibandingkan total rata - rata bobot penilaian setelah periode IPO yakni sebesar 51,16. Sesuai dengan trandnya periode sebelum IPO yakni 2011 - 2013 cenderung mengalami peningkatan hingga tahun IPO 2014 sedangkan pada periode setelah IPO cenderung mengalami penurunan dari tahun IPO 2014 hingga 3 tahun setelah IPO yakni tahun 2017. Jadi, dapat dikatakan IPO tidak memberikan dampak yang cukup baik terhadap tingkat kesehatan kinerja keuangan perusahaan. Kesimpulan ini berbeda dengan teori bahwa IPO akan memperoleh pengaruh yang besar dalam memperbaiki kondisi perusaahaan dan peningkatan kinerja keuangan. Untuk itu perusahaan perlu meningkatkan kinerja perusahaan. 


\subsection{Saran}

Berdasarkan kesimpulan di atas maka dapat dikemukakan beberapa saran, diantaranya:

1. Bagi Perusahaan

Diharapkan ke depannya perusahaan dapat lebih mempercepat pengumpulan piutang serta meningkatkan efektifitas penggunaan aktiva dan modal yang didapatkan dari hasil penjualan saham di pasar modal untuk menghasilkan kepuasan dan laba yang lebih besar bagi para investor.

2. Bagi Peneliti Selanjutnya

Kepada peneliti selanjutnya, khususnya yang berminat meneliti analisis kinerja perusahaan BUMN dan anak perusahaan BUMN diharapkan tidak hanya meneliti aspek keuangannya saja tapi juga menyertakan aspek operasional dan aspek administrasi sesuai dengan ketentuan Surat Keputusan Menteri BUMN No. KEP-100/MBU/2002.

\section{DAFTAR PUSTAKA}

Fahmi, Irham. 2012. Analisis Laporan Keuangan Cetakan Ke-2. Alfabeta, Bandung.

Harahap, Sofian Safri. 2010. Analisis Kritis Atas Laporan Keuangan. Rajawali Persada, Jakarta.

Hery. 2013. Teori Akutansi. Lembaga Penerbit Fakultas Ekonomi Universitas Indonesia, Jakarta.

Inayah. N. 2011. Analisis Kinerja Keuangan

Perusahaan Sebelum dan Sesudah Go

Public pada PT Jasa Marga Tbk di BEI

Periode Tahun 2004-2010

Ikatan Akuntan Indonesia 2017. Standar Akuntansi Keuangan PSAK No. 1. Salemba Empat, Jakarta.

Jumingan. 2011. Analisis Laporan

Keuangan. Bumi Aksara, Jakarta

Kasmir. 2015. Analisis Laporan Keuangan.

PT Raja Grafindo Persada, Jakarta.

Lasmana. A, W. Wijayanti, 2016. Analisis

Kinerja Keuangan Dalam Menilai

Tingkat Kesehatan Aspek Keuangan
Pada PT Garuda Indonesia Tbk

Periode 2011-2015. Berdasarkan Surat Keputusan Menteri BUMN Nomor:KEP-100/MBU/2002. Jurnal. Program Studi Fakultas Ekonomi Universitas Djuanda, Bogor

Munawir, S. 2010. Analisis laporan Keuangan Edisi keempat. Cetakan Kelima Belas. Liberty, Yogyakarta.

--------. 2012. Analisis Informasi Keuangan. Liberty, Yogyakarta.

Prastyo, Mihror Dendi, 2012. Analisis Kinerja Keuangan BUMN Yang Melakukan

Privatisasi Melalui IPO (Studi Kasus: PT. Wijaya Karya). Jurnal. Fakultas Ekonomi dan Manajemen Institut Pertanian Bogor, Bogor.

Purnomoratih, Yennie. 2008. Analilis Kinerja Keuangan PT Adhi Karya, Tbk sebelum dan sesudah Go Public. Skripsi. Fakultas Ekonomi Universitas Marcu Buana, Jakarta.

Riyanto, Bambang. 2011. Dasar-Dasar Pembelanjaan Perusahaan Edisi 4. BPFE-Yogyakarta, Yogyakarta.

Rudianto. 2013. Akutansi Manajemen Informasi untuk Pengambilan Keputusan Strategis. Erlangga, Jakarta.

Sawidji, 2009. Pasar Modal Indonesia Pengantar dan Studi Kasus, Cetakan Pertama, PT Ghalia Indonesia, Jakarta.

Setiawan, Indrianto. (2007). Analisis Kinerja Keuangan Perusahaan Sebelum dan Sesudah Initial Public Offering (IPO) (Studi pada Perusahaan Perbankan yang Terdaftar di Bursa Efek Jakarta Periode 1982-2006). Tesis. Program Studi Magister Manajemen Program Pasca Sarjana Universitas Diponegoro, Semarang.

Soemohadiwidjojo. Arini. T. 2015. Panduan Praktis Menyusun KPI. Penerbit Raih Asa Sukses (Penebar Swadaya Grup), Jakarta.

Sugiyono. 2014. Metode Penelitian 
Pendidikan Pendekatan Kuantitatif,

Kualitatif, dan R\&D. Alfabeta,

Bandung.

--------. 2016. Metode Penelitian

Kunatitatif Kualitatif dan R\&D.

Alfabeta, Bandung

Surat Keputusan Menteri Badan Usaha

Milik Negara Nomor: KEP-

100/MBU/2002 tentang Penilaian

Tingkat Kesehatan Badan Usaha Milik Negara. 2002. Jakarta.

Sutrisno. 2003. Manajemen Keuangan.

Teori konsep dan aplikasi, edisi pertama Ekonisia, Yogyakarta.

Sutrisno, Edi. 2009. Manajemen Sumber Daya Manusia Edisi pertama. Kencana Prenada Media Group, Jakarta.

Wirajunayasa dan Asri Dwija Putri. 2017. Analisis kinerja keuangan perusahaan sebelum dan sesudah Initial Public

Offering. E-Jurnal Akuntansi Universitas Udayana Vol.19.3.

Juni(2017): 1916-1942. 